\title{
In situ experiments on the dissolved and colloidal state of iron in an acid bog lake ${ }^{1}$
}

\author{
Jeffery $P$. Koenings ${ }^{2}$ \\ School of Natural Resources, University of Michigan, Ann Arbor 48104
}

\begin{abstract}
A samplcr and an analytical and characterization scheme were developed to investigate the chemical and physical state of iron in a highly stained acid bog lake (North Gate Lake). Iron fractions were chemically separated by reactivity to bathophenanthroline (BPN) after specific digestion procedures. Physical separation by anaerobic in situ filtration $(450 \mathrm{~nm})$ and in situ dialysis $(4.8 \mathrm{~nm})$ resulted in three size classes: particulate, colloidal, and dissolved.

Inorganic, nonreactive species of iron [e.g. $\left.\mathrm{Fe}(\mathrm{OH})_{3}\right]$ represent minor amounts of the total iron in North Gate Lake, in contrast to lakes of $\mathrm{pH}$ 6-8. In situ radiochemical analyses revcaled that colloidal reactive ferric iron predominates in the oxygenated epilimnion, while dialyzable or dissolved ferrous iron increases with depth. Unlike iron, organic matter is present in a nontransient colloidal state. In acid $(\mathrm{pH} \mathrm{4-5)} \mathrm{bog} \mathrm{lakes} \mathrm{ferric} \mathrm{iron} \mathrm{may} \mathrm{be}$ colloidal not as an inorganic complex $\left(\mathrm{OH}^{-}\right)$but as reactive $\mathrm{Fe}^{3+}$ by complexation with the colloidal organic acids.

After thermally induced mixing with anaerobic waters, ferric iron is reduced and dissolved; however some of the BPN reactive iron remains colloidal, suggesting the presence of a residual ferrous organic complex.
\end{abstract}

Inorganic iron may be present in the epilimnion of oxygenated lakes of $\mathrm{pH}$ 6-8 as $\mathrm{Fe}$ (III) hydroxides in the form of cither a precipitate or a sol (Hutchinson 1957; Shapiro 1964). Shapiro (1964) showed that organic acids could hold iron in apparent solution above $\mathrm{pH} 5$ as peptized sols. IIowever, at lower $\mathrm{pH}$, ionization of organic acids decreases, the rate of oxidation of iron becomes indepedent of $\mathrm{pH}$, and the solubility of all ionic forms of iron increases. Low $\mathrm{pH}$, combined with low oxygen tensions and a reducing environment containing colloidal organic matter (COM), may permit large amounts of ionic iron to be present without inorganic (hydroxyl ion) complexation in bog lakes. In addition, the low ionic strength of bog lake water, as indicated by the low conductivity (20-30 $\mu \mathrm{mhos} \mathrm{cm}^{-1}$ at $18^{\circ} \mathrm{C}$ ), reduces the coagulation formation of particulate forms of iron. Under these conditions, solution size, oxidation state, and organic acid complexation of ferrous and ferric iron may be

\footnotetext{
${ }^{1}$ Supported by U.S. Atomic Energy Commission contract AT(11-1)-1771.

"Present address: Environ. Sci. and Eng., Univ. North Carolina, Chapel IIill 27514.
}

quite different from those in lakes of neutral or basic pHI.

Low dissolved oxygen, high $\mathrm{CO}_{2}$, low $\mathrm{pH}$, and the presence of reducing organic and inorganic compounds all favor formation of ferrous iron. Decomposing organic residues (including "humic acid") can reduce ferric to ferrous iron or form ferrousorganic complexes (Bloomfield 1952). Shapiro (1966) showed that colored organic acids could reducc forric iron from natural waters, and Hem (1960) showed that tannic acid reduced forric iron in artificial laboratory systems. Divalent sulfur compounds (e.g. $\mathrm{H}_{2} \mathrm{~S}$ ) in lake waters can also reduce ferric iron (Stumm and Morgan 1970). All the above are encountered in highly colored acid bog water (pH 4-5) and tend to increase the solubility of iron by favoring the ferrous state. Bog lakes thereforc present complex systems for measurement of the physical and chemical states of iron. Sampling and analytical difficulties have created some uncertainties regarding the iron species at specific depths in the water column. My purpose here is to define more precisely the states of iron in acid bog lakes and to determine 
the in situ relationship of iron to COM in differentially oxygenated lake waters.

I thank F. F. Hooper, J. Shapiro, J. W. McMahon, P. Kilham, and J. Elder for reviewing the manuscript. I also thank R. E. Gordon for use of the Notre Dame tract, and $\mathrm{E}$. Baker for help in the iron analysis.

\section{Study area and methods}

The experiments were done in North Gate Lake, a small, highly colored, meromictic lake in Section 37 of T45N, R42W, Gogebic County, Michigan. It is one of many bog lakes on a 2,225 ha reserve owned by the University of Notre Damc, has a surface area of about $0.4 \mathrm{ha}$, and a maximum depth of $8 \mathrm{~m}$. The open water is surrounded by a Sphagnum mat which extends into a black spruce forest.

Measurements of the oxidation state and speciation of iron in lakes are difficult. The two oxidation states of iron and their various complexes may occur simultaneously at a given depth, both the oxidation state and coordination are very sensitive to dissolved oxygen, and the oxygen content of samples is easily altered during handling. Bathophenanthroline (BPN) was used to measure ferrous iron; it does not react with any other metal ion (including $\mathrm{Fe}^{3+}$ ). BPN gives a colored complex that can be extracted by $\mathrm{n}$-hexyl alcohol at $\mathrm{pH} 4.0$ to isolate the colored complex from its aqueous solution, increase sensitivity, and extend the specificity to the point where there is no known interference by either metal cations or common anions (Smith et al. 1952). The analytical scheme is shown in Fig. 1. All samples were duplicated and each digestion procedure contained a blank. Solutions were read in a Klett-Summerson colorimeter using the $4-\mathrm{cm}$ cell. Standards were run with each experiment.

Since $\mathrm{Fe}(\mathrm{II})$ is unstable in the presence of oxygen, samples are usually preserved at the time of collection. Preservation with acid accelerates the reduction of $\mathrm{Fe}$ (III) to $\mathrm{Fe}(\mathrm{II})$, releases iron from organic complexes, and dissolves inorganic ferrous salts (McMahon 1967; O'Connor et al. 1965). Thus, only total ferrous iron is measurable.

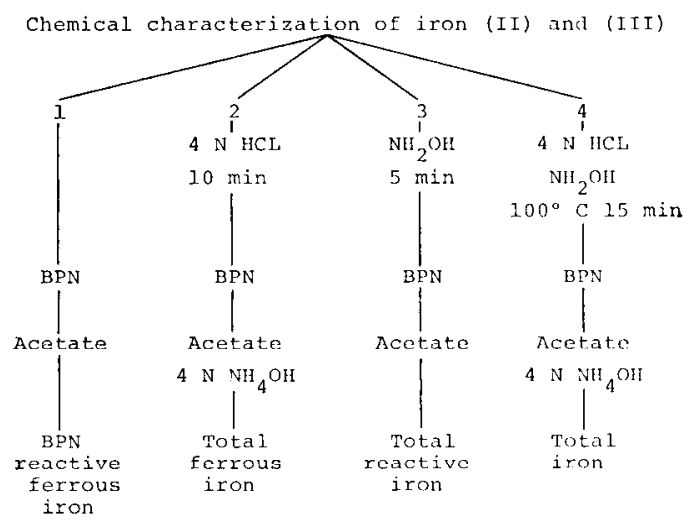

Fig. 1. Analytical scheme used to characterize iron species in North Gate Iake. Duplicate satuples $(25 \mathrm{ml})$ were carried through each procedure (1-4). After neutralization to $\mathrm{pH} 4.0$ with $\mathrm{NH}_{4}$ $\mathrm{OH}$, the red BPN-Fe(II) complex was extracted into n-hexanol, diluted with $95 \%$ ethanol, and the absorbance measured at $540 \mathrm{~nm}$. (See Golterman and Clymo 1969.)

Sunlight also interferes with the determination of ferrous iron by differentially reducing $\mathrm{Fe}$ (III) compounds.

To circumvent these problems I used a plastic in situ filtration sampler which yielded $200 \mathrm{ml}$ of a $0.45-\mu$ membrane-filtered sample (Fig. 2). Samples were collected with four airtight, light-proof samplers from the surface $(0-5 \mathrm{~cm})$, the top of the thermocline $(2 \mathrm{~m})$, the middle of the anaerobic hypolimnion $(5 \mathrm{~m})$, and the monimolimnion $(7.5 \mathrm{~m})$. Sampler containers were filled with a mixture of helium $(99.05 \%)$ and isobutane $(0.95 \%)$ and then transferred in a pressurized condition to the lake. A container was attached to a $0.45-\mu$ membrane-filtering apparatus and to filtration tubing connected to a vacuum pump. The apparatus was then lowered to the desired depth and filled with lake water by vacuum filtration. Sampler cylinders were returned to the laboratory under a slight negative pressure and a gas-filled balloon was fitted to the upper stopcock. Gas from the balloon entered the cylinder during the removal of subsamples from the lower stopcock.

Four analyses were performed on duplicate 25-ml samples from a series of depths 


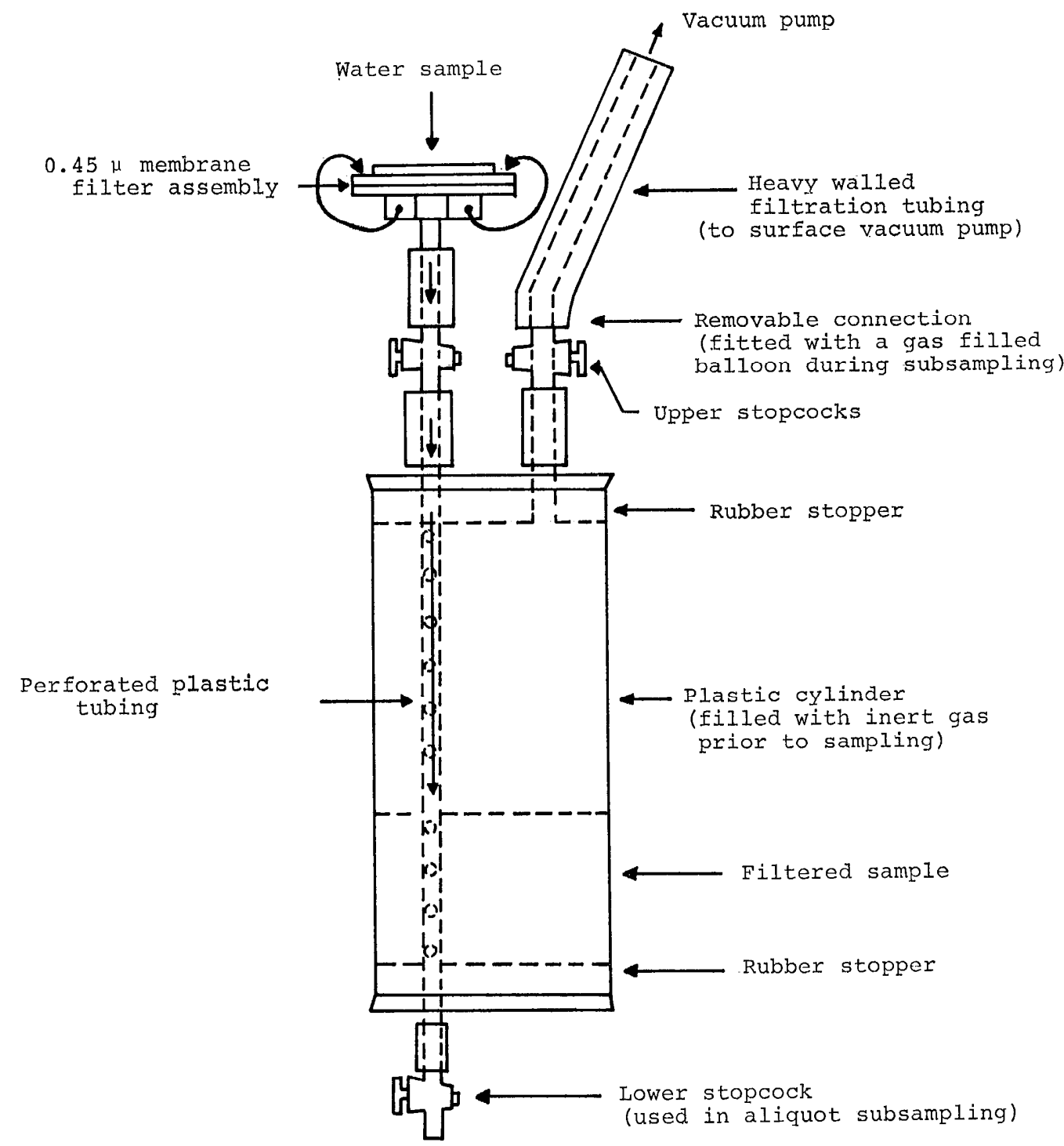

Fig. 2. In situ filtration device used to take $0.45-\mu$ membrane-filtered samples from four depths in North Gate Lake without interference from oxygen.

(Fig. 1, 1-4). Two of these included acid digestion, two did not. All were done within 20 min of time of collection. Analysis 1 consisted of the addition of BPN directly to a sample, followed by color development and hexanol extraction (McMahon $1969 b)$. Since acid dissolves insoluble ferrous salts (O'Connor et al. 1965), and releases $\mathrm{Fe}$ (II) from organic complexes (McMahon 1969a), the addition of BPN without acid measures only the BPN reactive form of ferrous iron $\left(\mathrm{Fe}^{2+}\right)$. Analysis 2 measured total ferrous iron (acid + BPN). Analysis 3 consisted of adding only a reducing agent, hydroxylamine hydrochloride $\left(\mathrm{NH}_{2} \mathrm{OH}\right)$, followed by $\mathrm{BPN}$, color development, and extraction. This measured total reactive iron, which includes $\mathrm{BPN}$ reactive ferrous iron, in addition to reactive ferric iron, which requires reduction 
alone to bring it to the BPN reactive state. The term nonreactive ferric iron is used here to describe all forms of iron that require hot acid digestion plus reduction for release to the BPN reactive state. This is similar to the procedure used by Stumm and Lee (1961) to measure colloidal ferric oxyhydroxide. Analysis 4 measured total iron (reductant + acid + heat) (Golterman and Clymo 1969).

Results from these four analyses were used as follows in calculations of iron species-

analysis $1=\mathrm{BPN}$ reactive ferrous iron; analysis $2-$ analysis $1=$ nonreactive forrous iron;

analysis 3 -analysis 1 = reactive ferric iron (result A);

analysis $4-$ analysis $2=$ total ferric iron (result $\mathrm{B}$ );

result $\mathrm{B}$-result $\mathrm{A}=$ nonreactive ferric iron.

These categories can be described as dissolved, colloidal, etc. if the water has been appropriately pretreated. The effectiveness of the above characterization scheme in differentiating between dissociated and undissociated iron as well as between ferrous and ferric iron was tested by analyzing freshly prepared iron standards of known concentration. These compounds do not exist in nature, but they do demonstrate the reactivity of known forms of iron to the proposed reaction scheme, from which natural lake iron was later classified. The replicability of the BPN method was excellent. Eight samples containing $10 \mu \mathrm{g}$ of iron were analyzed for total iron with a standard error of $0.02 \mu \mathrm{g}$.

Samples were taken on 19 and 21 July by in situ anaerobic filtration at the four sampling depths in the center of the lake, and on 24 July and 24 August with a modified Hale sampler with acid-washed $300-\mathrm{ml}$ BOD bottles, transported to the laboratory with minimal exposure to light or atmospheric oxygen, filtered through $0.45-\mu$ membranes in the presence of air, and the analytical and characterization schemes described above were applied. Conductivity, $\mathrm{pH}$, alkalinity, temperature, dissolved oxy- gen, and total iron were monitored continuously from 12 May to 10 August. These parameters did not change after 1 June. A stable thermocline $(2 \mathrm{~m})$ develops early in North Gate Lake with chemical and physical parameters remaining nearly constant until the fall overturn of the mixolimnion. Day-to-day variations were small, permitting comparison of samples collected in the same location but analyzed with different procedures on successive datcs. Duplicated experiments agreed very well and were averaged to show the naturally existing species of iron in different strata of the lake and the effects of aeration (aerobic filtration) on the species of iron present.

To determine both the natural physical state and the movement of iron in acid bog waters, ${ }^{59} \mathrm{Fe}-\mathrm{FeCl}_{3}(1.0 \mathrm{mCi})$ was carefully added to the surface $(7.0 \mathrm{~cm})$ of a column of lake water contained in a polyethylene cylinder $1 \mathrm{~m}$ in diameter and $8 \mathrm{~m}$ deep. The tracer increased the amount of iron in the surface water by less than $1 \%$. An evacuated bottle was used to draw samples from a series of glass sampling tubes spaced at $1-m$ intervals down the center of the tube, through connecting tygon tubing; a volume of water equal to that of the tubing volume was discarded before sampling. Samples were taken to the laboratory, filtered, and total and filterable activity was measured by drying triplicate 5-ml subsamples on planchets and counting on a low background beta counting system. Rates of movement of the tracer were equal to the slope of the least squares regression estimate for the change in ${ }^{50} \mathrm{Fe}$ activity with time after correcting for isotopic decay. A total radioactive iron budget was calculated for the plastic cylinder to determine any loss of tracer out of the epilimnion during the experiment.

To characterize further the physical state of the iron, I installed sealed sections of acid-cleaned $(10 \% \mathrm{HCl})$ cellulose dialysis tubing (pore diameter of $4.8 \mathrm{~nm}$, or molecular weight cutoff for proteins of $>12,000$ ) containing distilled water inside the cylinder, at $1-\mathrm{m}$ intervals, 5 days after the tracer was introduced. After another 5 days triplicate 5-ml samples were withdrawn from 
Table 1. Iron standards characterized by the proposed analytical scheme showing the separation of differentially reactive iron species. (Values are in percent of total iron.)

\begin{tabular}{|c|c|c|c|c|c|}
\hline & \multicolumn{4}{|c|}{ Iron Standards } \\
\hline & & $\begin{array}{c}\text { Bl'N } \\
\text { reactive } \\
\text { ferrous } \\
\text { i.ron } \\
\end{array}$ & $\begin{array}{l}\text { Non- } \\
\text { reactive } \\
\text { ferrous } \\
\text { iron }\end{array}$ & $\begin{array}{l}\text { Reactive } \\
\text { ferric } \\
\text { iron }\end{array}$ & $\begin{array}{l}\text { Non- } \\
\text { reactive } \\
\text { ferric } \\
\text { iron }\end{array}$ \\
\hline (1) & $\begin{array}{l}\text { ferric } \\
\text { oxyhydroxide } \\
\text { ferric }\end{array}$ & 0.0 & 0.0 & 16.0 & 81.0 \\
\hline (3) & $\begin{array}{l}\text { chloride } \\
\text { terric } \mathrm{NIL}_{4}\end{array}$ & 0.0 & 0.0 & 16.0 & 84.0 \\
\hline (4) & $\begin{array}{l}\text { sulfate } \\
\text { ferric }\end{array}$ & 0.0 & 0.0 & 12.0 & 88.0 \\
\hline (5) & $\begin{array}{l}\text { perchlorate } \\
\text { ferric }\end{array}$ & 0.0 & 0.0 & 100.0 & 0.0 \\
\hline & citrate & 0.0 & 0.0 & 100.0 & 0.0 \\
\hline (6) & forric I:D'TA & 0.0 & 0.0 & .100 .0 & 0.0 \\
\hline (7) & $\begin{array}{l}\text { ferrous } \mathrm{NII}_{4} \\
\text { sulfate }\end{array}$ & 95.0 & 5.0 & 0.0 & 0.0 \\
\hline
\end{tabular}

inside the tubing, evaporated to dryness, and counted. I determined the period of 5 days for quantitative equilibrium of the dialysate with the surrounding water using ${ }^{5}{ }^{2} \mathrm{Fe}-\mathrm{FeCl}_{3}$ and $\mathrm{FeCl}_{3}$ standard solutions at $20^{\circ}$ and $5^{\circ} \mathrm{C}$.

The fractions were defined as: materials $>0.45 \mu$, particulate; those $<0.45 \mu$, but $>4.8 \mathrm{~nm}$, were colloidal; those $<4.8 \mathrm{~nm}$, truly soluble or dissolved.

\section{Results}

Standard iron solutions-All solutions were analyzed at $\mathrm{pH} 4-5$ with $400-500 \mu \mathrm{g}$ liter ${ }^{1}$ of iron present. Ferrous ammonium sulfate reacted as ferrous iron $(100 \%)$ and as BPN reactive ferrous iron ( $95 \%$ ) (Table $1) ;<5 \%$ reacted as nonreactive ferrous iron. Ferric ammonium sulfate, ferric chloride, and most important, ferric oxyhydroxide, all reacted as forric iron $(100 \%)$ and were calculated to be nonreactive ferric iron compounds $(84-88 \%)$. These ferric compounds, unlike the ferrous iron, did not react as free dissociated (hydrated) iron but required acid digestion plus reduction to be reactive to BPN. The ability of ferric iron to form incompletely dissociatcd inorganic complexes with sulfate and chloride is well known (Cooper 1937; Rabinowich and Stockmayer 1942; Stumm and Lee 1960). The results given are from freshly prepared standards. Aged solutions (3-5 days) of ferric chloride and ferric oxy-
Table 2. Size classification of ${ }^{59} \mathrm{Fe}$ activity following addition of tracer to a water column enclosed in a plastic cylinder in North Gate Lake (A), and stable iron distribution in North Gate Lake using in situ dialysis (B).

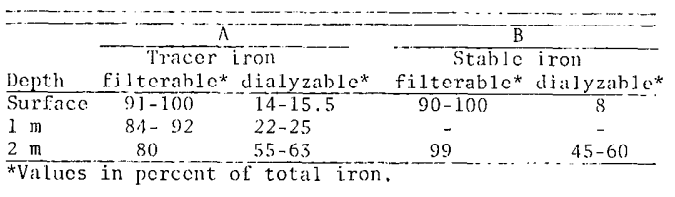

hydroxide yielded recoveries as nonreactive ferric iron of $96 \%$.

Ferric perchlorate reacted as reducible ferric iron and was entirely reactive ferric iron that required reduction alone to react with BPN. The perchlorate anion does not form an inorganically bound complex with iron to the degree of sulfate, chloride, or hydroxide. Thus, reactive ferric iron represents iron morc in the completely dissociated $\mathrm{Fe}^{3+}$ state. However, reactive ferric iron need not be in the free state, as iron organically complexed (e.g. ferric EDTA and ferric citrate) also was present in the reactive state. Lake iron in the ferric reactive state is therefore primarily dissociated iron $\left(\mathrm{Fe}^{3+}\right)$ present either free (hydrated) or organically complexed. Since free (hydrated) ferric iron would be dialyzable, reactive iron in bog lake waters of colloidal size could exist as COM-bound iron rather than an inorganic colloid. If colloidal and reactive, the iron may be present in an organic complex with COM, but if colloidal and nonreactive, the iron is more likely to be present as an inorganic colloid, c.g. ferric oxyhydroxide.

The rationale is, then, that although dissociated iron will react with BPN without acid, inorganically complexed iron will not react until the appropriate acid digestion procedure renders the iron reactive. The above classification scheme, together with sizo separation by in situ filtration and dialysis, yielded a characterization scheme for acid bog lake iron.

Lake iron-Levels of iron in North Gate Lake were in the highest range of values for similar lakes found by Juday et al. (1938). Many of the lakes of this region 
Table 3. Distribution of the natural species of filterable iron in North Gate Lake following in situ $(0.45 \mu)$ filtration $(A)$, and the distribution of filterable iron species in the same strata following aerobic $(0.45 \mu)$ filtration (B). (Values are in $\mu \mathrm{g} \mathrm{liter}{ }^{-1}$.)

\begin{tabular}{|c|c|c|c|c|c|c|c|c|c|c|}
\hline \multirow{2}{*}{$\begin{array}{l}\text { Depth } \\
(\mathrm{m}) \\
\end{array}$} & \multicolumn{2}{|c|}{$\begin{array}{c}\text { BPN reactive } \\
\text { Fe }(+2)\end{array}$} & \multicolumn{2}{|c|}{$\begin{array}{l}\text { Nonreactivo } \\
\text { Fe (II) }\end{array}$} & \multicolumn{2}{|c|}{$\begin{array}{l}\text { Reactive } \\
\mathrm{Fe}(+3)\end{array}$} & \multicolumn{2}{|c|}{$\begin{array}{l}\text { Nonreactive } \\
\mathrm{Fe} \text { (IIT) }\end{array}$} & \multicolumn{2}{|c|}{ Tota 1} \\
\hline & $A$ & $B$ & $\bar{\lambda}$ & $\mathrm{B}$ & $A$ & $\bar{B}$ & $\Lambda$ & $\mathrm{B}$ & $\overline{\mathrm{A}}$ & $\bar{B}$ \\
\hline 0 (surfacc) & $\overline{73}$ & 42 & 46 & 19 & 119 & 93 & 26 & 140 & 264 & 294 \\
\hline 2 (metalimnion) & 426 & 182 & 36 & 16 & 84 & 241 & 49 & 168 & 595 & 607 \\
\hline 5 (hypolimnion) & 634 & 366 & 3 & 126 & 8 & 160 & 32 & 24 & 677 & 676 \\
\hline 7.5 (monimolimnion) & 1073 & 610 & 4 & 228 & 0 & 279 & 79 & 37 & 1161 & 1154 \\
\hline
\end{tabular}

are highly stained. In North Gate I Lake yellow colloidal organic matter comprises up to $85 \%$ of the total organic carbon, and $90-100 \%$ of the total iron is $0.45-\mu$ membrane filterable (Table 2 ). This large fraction of filterable iron suggests that the presence of $30-40 \mathrm{mg}$ liter ${ }^{-1}$ COM, combined with low $\mathrm{pH}$ and conductivity, prevents formation of large iron polymers. Total filterable iron increased from $264 \mu \mathrm{g}$ liter $^{-1}$ at the surface to 1,161 in the monimolimnion, and BPN reactive ferrous iron, measured after in situ filtration, increased from 28 to $93 \%$ of total iron (Table 3 ). Since oxygen was absent below $2 \mathrm{~m}$, it is not surprising that iron was present almost exclusivcly as BPN rcactive ferrous iron. However, it is interesting that reactive ferric iron on the dates sampled represented $78-90 \%$ of the ferric iron in the surface water, in turn an average of $45 \%$ of the total iron, and that I did not find large amounts of nonreactive $\mathrm{Fe}$ (III) (e.g. ferric oxyhydroxide) at any depth sampled. These values represented $<10 \%$ of total iron. BPN reactive $\mathrm{Fe}(\mathrm{II})$ and reactive $\mathrm{Fe}$ (III) (i.e. from acid-free analysis), which increased from $73 \%$ in the epilimnion to $95 \%$ in the hypolimnion, thus represented a majority of the iron present. The small romaining fractions in these two strata were acid-digestible nonreactive iron $[\mathrm{Fe}$ (II) and/or $\mathrm{Fe}$ (III)].

The reducing COM in the hypolimnion does not form a complex with ferrous iron more stable than the $\mathrm{BPN}-\mathrm{Fe}^{2+}$ complex. The predominant form of $\mathrm{Fe}$ (II) was $\mathrm{BPN}$ reactive, contrary to the suggestion of Gjessing (1964) that $\mathrm{Fe}$ (II) in highly colored, pH 4-6 Norwegian waters existed as organic complexes reactive only after hot acid digestion. The oxygenated epilimnion contains principally reactive ferric iron ( $84 \%$ of ferric iron) and little ferric oxyhydroxide. The 2-m stratum, with $0.50 \mathrm{mg}$ liter ${ }^{-1}$ dissolved oxygen, also contains reactive ferric iron and appears to be the zone in which the downward-diffusing dissolved oxygen first oxidizes the $\mathrm{Fe}(\mathrm{II})$ diffusing upward from the anaerobic hypolimnion.

In the low pH range $(4-5)$ of the surface water of North Gate Lake, the reactive form of $\mathrm{Fe}(\mathrm{III})$ is the predominant form of iron. However, even though environmental conditions in these waters allow $\mathrm{Fe}$ (III) to exist chemically in a reactive state, the stable iron analysis and radiochemical data presented below indicate that this is in colloidal form.

Labeling experiment-Working on highly stained lake waters from Alaska, Barsdate (1970) found that $80 \%$ of the cobalt and $68 \%$ of the manganese (in addition to the organic acids) were retained by dialysis bags. He belicved that this was due to the formation of complexes and associations between metals and the highly dispersed organic colloids. To makc an in situ test of this hypothesis in North Gate Lake, ${ }^{59} \mathrm{Fe}-\mathrm{FeCl}_{3}$ was carefully added to the surface water in the polyethylene cylinder in the lake after thermal equilibrium had becn established with the surrounding water (Fig. 3). Slow exchange with the 1-m stratum took place until cool weather and wind mixed the upper two layers (day 5). Slow vertical leakage then occurred from the 1-m layer through the thermocline for the rest of the 11-day experiment.

Marshall and LeRoy (1972) showed that ${ }^{59} \mathrm{Fe}$ equilibrated with the particulate 


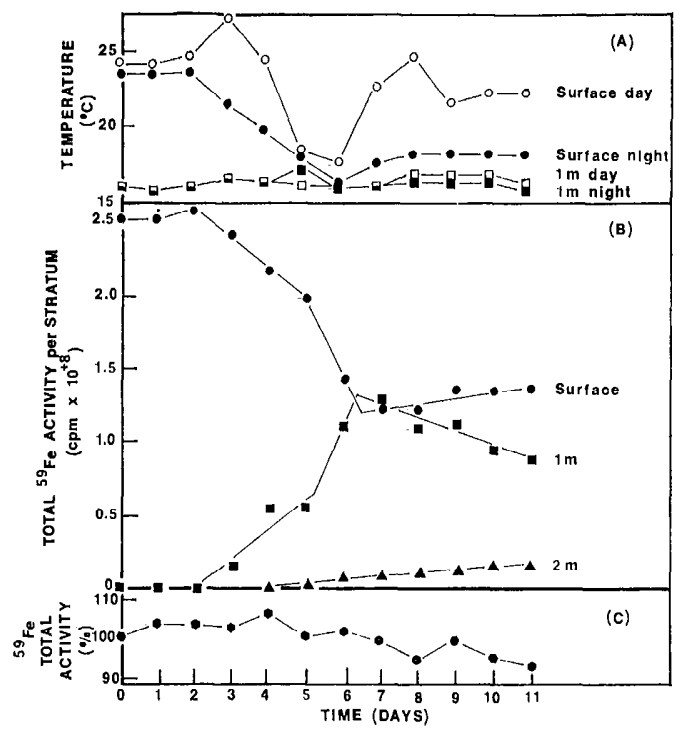

Fig. 3. Tracer $\left({ }^{59} \mathrm{Fe}\right)$ cylinder experiment in which the changing thermal regime of the lake water (A) caused the movement of ${ }^{50} \mathrm{Fe}$ added to the surface stratum to lower strata (B), and the total tracer budget for the epilimnion of the cylin$\operatorname{der}(\mathrm{C})$.

inorganic iron of a South Carolina reservoir within $24 \mathrm{~h}$, and that on the average $65 \%$ of the iron was particulate. In the surface waters of North Gate Lake, 91$100 \%$ of the total activity was filterable and only $15.5 \%$ of the filterable activity was dialyzable after 11 days, but at $2 \mathrm{~m}$, up to $63 \%$ of the total activity was dialyzable. The pcrcentage increase in the dialyzable activity fraction from the surface to $2 \mathrm{~m}$ was similar to but lower than the increase in BPN reactive ferrous iron ( 28 to $72 \%$ ) between these two strata and reflects increasing reduction and release of colloidal to dissolved iron with increasing depth (Tables 2 and 3 ).

Colloidal $\mathrm{Fe}$ (III) of the surface water moved down in the cylinder and was reduced to dissolved iron $[\mathrm{Fe}(\mathrm{II})]$. This movement was caused by cooling of the the surface water and thermal equilibration between the 1-m and surface strata (Fig. 3). During the cooling period (days 2-5) the rate of loss $\left(-0.210 \times 10^{+8} \mathrm{cpm} \mathrm{d}^{-1}\right)$ of activity from the surface agreed well with the increase of $+0.185 \times 10^{+8} \mathrm{cpm} \mathrm{d}^{-1}$ at $1 \mathrm{~m}$ before mixing. These rates increased to $-0.546 \times 10^{+8} \mathrm{cpm}$ and $+0.576 \times 10^{+8}$ cpm during mixing (days 5-6). The combined rate of loss of tracer from the surface $\left(0.756 \times 10^{+8} \mathrm{cpm} \mathrm{d}^{-1}\right)$ agreed with the increasc at $\mathrm{I} \mathrm{m}\left(0.759 \times 10^{+8} \mathrm{cpm} \mathrm{d}^{-1}\right)$. On day 6 , the recovery of added tracer was $102 \%$. After thermal equilibration (day 6) no further tracer was lost at the surface layer through day 11 , when ${ }^{59} \mathrm{Fe}$ activity at the surface layer represented $>50 \%$ of the added iron. $\Lambda$ fter mixing, activity was lost from the $1-\mathrm{m}$ stratum at the rate of $-0.0953 \times 10^{+8} \quad \mathrm{cpm} \quad \mathrm{d}^{-1}$, a significantly lower rate than the rate of loss at the surface (days 2-5). Howcver, unlike the surface to $1-\mathrm{m}$ mixing, the loss was not balanced by the total rate of ${ }^{59} \mathrm{Fc}$ increase at other depths $\left(2 \mathrm{~m},+0.0190 \times 10^{+8} \mathrm{cpm}\right.$; surface, $+0.0346 \times 10^{+8} \mathrm{cpm} ; 3 \mathrm{~m},+0.0012$ $\times 10^{18} \mathrm{cpm}$ ), suggesting that $42 \%$ of the loss from $1 \mathrm{~m}$ either was held in strata which were not sampled or had become concentrated between 1 and $2 \mathrm{~m}$. The unaccounted for loss of tracer from $1 \mathrm{~m}$, $-0.0405 \times 10^{+8} \mathrm{cpm} \mathrm{d} \mathrm{d}^{-1}$ for the 5-day period following mixing equals $-0.2025 \times 10^{+8}$ $\mathrm{cpm}$, is $8 \%$ of the total ${ }^{59} \mathrm{Fe}$ added. This loss, possibly held at the top of the thermocline, appears to bo responsible for the slight underrecovery (92\%) calculated for the total iron budget at the end of the cylinder experiment.

During the entire experiment, 80-100\% of the traccr was filterable at all depths sampled. In this acid bog lake particulate polymers of iron constituted a minor fraction of the total iron and iron was not removed from the epilimnion by precipitation and sedimentation. The predominant form of ferric iron is colloidal. As the colloidal ferric iron moved to deeper layers, it was reduced to dissolved ferrous iron. However, a colloidal form of BPN reactive iron (II) also appcared to be present: at $2 \mathrm{~m}$ $72 \%$ was BPN reactive ferrous iron and only $63 \%$ dialyzable ferrous iron.

In summary, the organic matter in North Gate Lake docs not require sorption to colloidal inorganic ferric iron to be nondialyzable. Along with the COM, the iron of the 
surface waters was primarily colloidal, but did not react as an inorganic colloid. The iron spccies of the surface waters [primarily reactive $\mathrm{Fe}$ (III) ] thus may be colloidal due to complexation with COM. Although at $2 \mathrm{~m}$ ferrous iron shows significantly less affinity for the colloidal state and appears to be in a dissolved ionic state, a small fraction of COM bound ferrous iron may also be present.

Comparison with aerobic filtered samples-Aerobically filtered $(0.45-\mu$ membrane) samples were characterized by the same reaction series used for in situ filtered samples (Table 3). Since these samples were not and could not be subsamples of the anaerobic samples, but were from the same water layer, exact microgram per liter comparisons are not valid. However, I feel that the relative forms of iron can be compared, as shown by the high degree of similarity betwcen the iron species and the total iron within each of the replicated aerobic (24 July and 24 August) and anaerobic (19 July and 21 July) experiments. Although the results within the replicated experiments were similar, large differences between the aerobic and anacrobic results cannot be attributed to spatial or temporal variations in the depths sampled.

Exposure to air during filtration (1-5 min) results in major shifts in iron species. In the oxygenated waters of the epilimnion, aerobic filtration caused BPN reactive $\mathrm{Fe}$ (II), nonreactive $\mathrm{Fe}$ (II), and reactive $\mathrm{Fe}$ (III) to decrease and nonreactive $\mathrm{Fe}$ (III) (perhaps ferric oxyhydroxide) to increase. These changes indicate that the filterable iron in the surface water is in a chemical state which is changed by further acration. In the partially oxygenated water at $2 \mathrm{~m}$, filtration brought about a decrease in $B P N$ reactive $\mathrm{Fe}(\mathrm{II})$ and nonreactive $\mathrm{Fe}$ (II) and an increase in reactive $\mathrm{Fe}$ (III) and in nonreactive Fe(III). Aerobic filtration of completely deoxygenated water from 5 and $7.5 \mathrm{~m}$ resulted in similar responses (Table 3 ). In the anacrobic monimolimnion $(7.5 \mathrm{~m}), 41 \%$ of $\mathrm{BPN}$ reactive $\mathrm{Fe}$ (II) was lost by aeration, $20 \%$ appeared as nonreactive $\mathrm{Fe}(\mathrm{II})$, and $24 \%$ appeared as reactive $\mathrm{Fe}(\mathrm{III})$. Nonreactive $\mathrm{Fe}$ (III) was not formed. In the two equally deoxygenated strata ( 5 and $7.5 \mathrm{~m}$ ), the percentage of BPN reactive ferrous iron lost by aeration was identical (43\%) and the percentages of nonreactive $\mathrm{Fe}(\mathrm{II})$ and reactive $\mathrm{Fe}$ (III) that appeared were very close. Since responses to aeration in these strata were similar, whereas the response of strata with different oxygen content (surface and $2 \mathrm{~m}$ ) differed considerably, the in situ oxygen content seems to regulate changes that takc place on aeration. Apparently the overall trend is successive conversion of iron to a more oxidized and nonreactive state on aeration of samples from different depths. However, on aeration of the anaerobic lake water, a major increase occurred in reactive $\mathrm{Fe}$ (III), suggesting that COM may retard the formation of nonreactive $\mathrm{Fe}$ (III). This may also happen in natural lake water since the former state of iron predominates in the surface waters of North Gate Lake.

\section{Discussion}

When lake stratification is destroyed, any dissolved $\mathrm{Fe}^{2+}$ in the hypolimnion is oxidized and if the $\mathrm{pH}$ is greater than 6.0 , the $\mathrm{Fe}^{3+}$ ions that are formed precipitate as $\mathrm{Fe}(\mathrm{OH})_{3}$. Thus, in the oxygenated epilimnion of neutral to basic pH lakes, ferrous iron is not detectable and iron cannot be in true solution above $17 \mu \mathrm{g}$ liter ${ }^{-1}$. Since lakes contain iron above this level, Shapiro (1967) proposed, and demonstrated in laboratory studies, the capacity of concentrated or chemically extracted organic acids or their salts to hold large amounts of iron in apparent solution. IIe concluded that the mechanism of "solubilization" of iron at high $\mathrm{pH}$ and redox potential is the formation of a protected sol of colloidal inorganic ferric iron. Peptized sol formation has bccome widely accepted as the mechanism through which organic matter complexes with iron (IIutchinson 1957; Stumm and Morgan 1970).

Acid bog lakes are different from the systems on which a majority of the iron studies have been done. The presence of a large amount of $\mathrm{COM}$, high $\mathrm{CO}_{2}$ levels, 
low conductivity and alkalinity, and an acid (4-5) $\mathrm{pH}$ may result in iron species and relationships different from those previously reported. Elder (1975) demonstrated in theory that an acid pH alone may drastically de-cmphasize the importance of hydroxyl ion as a ligand for metal ions. A tenfold change in the hydroxide concentration of the water can produce changes in species of several orders of magnitude, even for iron, whose nonhydroxyl coordination is commonly considered negligible. Thus, in acid bog lakes ligands other than hydroxyl ion may be important in complexing iron when dissolved $\mathrm{Fe}^{2+}$ is oxidized to $\mathrm{Fe}^{3+}$ ions.

My in situ stable and radiochemical studies support the laboratory findings of a colloidal form of iron only in those oxygenated epilimnetic waters where ferric iron predominates. In acid bog lakes, colloidal iron consists of many reactive species of iron II and III, and fcrric iron rcacting as a colloidal inorganic complex [e.g. sol of $\mathrm{Fe}(\mathrm{OH})_{3}$ ] is notably lacking. By chemical reactivity about $84 \%$ of ferric iron is potentially dialyzable reactive $\mathrm{Fe}$ (III). Since the reactive ferric iron is not dialyzable, the colloidal size of this specics can be explained by complexation with preexisting COM. The ligands present in COM appear to be important in complexing reactive iron at the low $\mathrm{pH}$ values encountered in bog lake waters. Although colloidal reactive ferric iron is the major form of iron in aerobic strata, ferrous iron is also present, not in tracc amounts, but up to $45 \%$ of the total iron. High amounts of ferrous iron can be maintained in partially oxygenated water by photoreduction of complexed reactive $\mathrm{Fe}^{3+}$. Other organic reactive $\mathrm{Fc}^{3+}$ compounds (ferric citrate and ferric EDTA) can be photoreduced to moderately stable ferrous compounds if not subjected to oxidizing conditions (Jones and Long 1952).

In summary, the forms of ferric and ferrous iron prevalent in North Gate Lake were those not requiring acid digestion to be reactive to $B P N$, an indication of a lack of inorganic [ $\mathrm{Fe}(\mathrm{III})$ and $\mathrm{Fe}(\mathrm{II})]$ iron polymers. The hydroxyl ion concentration in North Gate Lake is up to 10,000 times less than that in pH 8 lakes from which most of the published iron data have been derived. In these low $\mathrm{pH}$ lakes, ferric iron is in a colloidal reactive state through complexation with the colloidal-sized organic ligands (COM) rather than through inorganic $\left(\mathrm{OH}^{-}\right)$complexation and nonreactive ferric iron [i.e. $\mathrm{Fe}(\mathrm{OH})_{3}$ ] is present in minor quantities. Instead of organic matter sorbing at the surface of colloidal inorganically complexed iron [ $\mathrm{sol}$ of $\mathrm{Fe}(\mathrm{OH})_{3}$ ] as in lakes of $\mathrm{pH} 8$, iron in the reactive state $\left(\mathrm{Fe}^{3+}\right)$ is complexed by COM in highly stained bog lakes of pH 4-5. This form of iron once reduced could account for the residual $\mathrm{Fe}^{2+}$-colloidal $\mathrm{BPN}$ reactive iron found in strata that had recently become anaerobic.

I feel that in lake waters of pII 4-5 the iron species present and their reactivities are not adequately explained by sol formation. The chemical environment of stained (COM) acid bog lakes differs from lakes of pII 6-8 in which iron is soon precipitated as an acid-digestible inorganic complex $\left[\mathrm{Fe}(\mathrm{OH})_{3}\right]$ and ferrous iron is not usually present. I, therefore, propose two mechanisms for the binding of iron to organic matter. The first predominates in highly colored bog waters ( $\mathrm{pH}$ 4-5) where the colloidal nature of iron is imparted by the high molccular weight organic acid (or organic sol) with its bound reactive $\mathrm{Fe}$ (III) and $\mathrm{Fe}(\mathrm{II})$. A second mechanism predominates in nonstained lake waters ( $\mathrm{pH}$ 7-9), where the colloidal particle may be a nonreactive iron sol [c.g. $\left.\mathrm{Fe}(\mathrm{OII})_{3}\right]$ maintained in apparent solution by sorption of organic acids to the iron colloid. The changes in organic matter and, in particular, in iron with changes in $\mathrm{pH}$ (i.e. the $\mathrm{OH}^{-}$ligand) allow for a differential binding of iron to organic acids above and below pII 6-7.

Thus, by determining the physical and chemical states of iron in natural waters, pII in combination with the type and quantity of organic matter may control the relative roles of iron and organic matter in lake 
waters. Since flocculation and subscquent precipitation of iron has been linked to phosphate elimination from trophogenic waters of neutral to basic lakes, the interaction of iron to phosphate might also differ in acid bog lakes.

\section{References}

Barsidate, R. J. 1970. Transition metal binding by large molecules in high latitude waters, p. 485-493. In D. W. Hood [ed.], Organic matter in natural waters. Inst. Mar. Sci. (Alaska) Occas. Publ. 1.

Bloomfield, C. 1952. Translocation of iron in podzol formation. Nature 170: 540.

Coopen, L. H. N. 1937. Some conditions governing the solubility of iron. Proc. R. Soc. Lond. Ser. B 124: 299-307.

Elder, J. F. 1975. Complexation side reactions involving trace metals in natural water systems. Limnol. Oceanogr. 20: 96-102.

GJessing, E. T. 1964. Ferrous iron in water. Limnol. Oceanogr. 9: 272-274.

Golterman, H. L., and R. S. Cuymo. 1969. Methods for chemical analysis of fresh waters. Blackwell.

HeM, J. D. 1960. Complexes of ferrous iron with tannic acid. U.S. Geol. Surv. Water Supply Pap. 1459-D, p. 75-94.

Hutchinson, G. E. 1957. A treatise on limnology, v. 1. Wiley.

Jones, S. S., AND F. A. Long. 1952. Complex ions from iron and ethylenediaminetctraacetate: Gencral properties and radioactive exchange. J. Phys. Chem. 56: 25-33.

Juday, C., E. A. Birge, and V. W. Meloche. 1938. Mincral content of the lake waters of northwestern Wisconsin. Trans. Wis. Acad. Sci. 31 : 223-276.

McMafion, J. W. 1967. The influence of light and acid on the measurement of ferrous iron in lake water. Limnol. Oceanogr. 12: 437442.

- 1969a. The annual and diumal variation in the vertical distribution of acid soluble ferrous and total iron in a small dimictic lake. Limnol. Occanogr. 14: 347-367.

- 1969b. An acid-free bathophenanthroline method for measuring dissolved ferrous iron in lake water. Water Res. 3: 743-748.

Marshali, J. S., AND J. II. LeRoy. 1972. Iron, manganese, cobalt, and zinc cycles in a South Carolina reservoir, p. 465-473. In D. J. Nelson [ed.], Radionuclides in ecosystems. Proc. Symp. Radioecol. (3rd). CONF. 710501-P1. NTIS.

O'Connor, J. T., K. Komolrit, and R. S. Engel1316cirT. 1965. Evaluation of the orthophonanthroline method for ferrous-iron determination. J. Am. Water Works Assoc. 57: 926-934.

Rabinowicit, L., and W. H. J. Stockmayer, 1942. Association of ferric ions with chloride, bromide, and hydroxyl ions (a spectroscopic study). J. Am. Chem. Soc. 64: 335347.

Shapino, J. 1964. Effect of yellow organic acids on iron and other metals in water. J. Am. Water Works Assoc. 56: 1062-1082.

- 1966. On the measurement of ferrous iron in natural watcrs. Limnol. Occanogr. 11: 293-298.

. 1967. Yellow organic acids of lake water: Differences in their composition and bchavior, p. 202-216. In II. L. Golterman and R. S. Clymo [eds.], Chemical environment in the aquatic habitat. North-Holland.

Smitis, F. G., W. H. McCurdy, JR., AND H. DreIIL. 1952. The colorimetric determination of iron in raw and treated municipal water supplies by use of $4: 7-$ Diphenyl-1 : 10 Phenanthroline. Analyst 77: 418-422.

Stumm, W., ANd G. F. Lee. 1960. The chemistry of aqueous iron. Schweiz. Z. Hydrol. 22: 295-319.

—, AND 1961. Oxygenation of ferrous iron. Ind. Eng. Chem. 52: 143-146. - And J. J. Morgan. 1970. Aquatic chemistry. Wiley.

Submitted: 9 April 1974 Accepted: 8 March 1976 